\title{
Enhanced Food Production by Applying a Human Rights Approach - Does Brazil Serve as a Model of Best Practice?
}

\author{
Hans Morten Haugen \\ Diakonhjemmet University College, Oslo \\ Norway
}

\section{Introduction}

The ignorance of agriculture in development policy circles that prevailed in most of the 1980s and 1990 has finally come to an end. Agriculture, including the right use of the land, is considered central for the following objectives:

a. Overcoming poverty, as GDP growth from agriculture is found to be overall twice as effective in reducing poverty as GDP growth derived from other sectors; and GDP growth originating in agriculture benefits the poorest half of the population substantially more (World Bank, 2007, 6)

b. Mitigating climate change, by promoting 'low greenhouse gas agriculture' (Food and Agricultural Organization (FAO), 2009, Nellemann et al. 2009, IPCC 2007, chapter 8, IAASTD, 2009, 538).

c. Reducing imports of food, in order to avoid becoming vulnerable to volatile prices on the world market; note in this context that Brazil, which relies on a global market for food, recognizes the concept of food sovereignty, most notably in Article 5 of the Law 11.346 of 2006 on a National Food and Nutrition Security System (SISAN), which reads (extract): "countries must be guaranteed the supremacy of their own decisions regarding food production and consumption."

d. Enhancing energy security, as in the case of Brazil, where ethanol from sugarcane has bypassed petrol as the dominant fuel, while the sugarcane currently occupies less than one per cent of (the best) agricultural lands in Brazil.

It might be difficult to achieve all these objectives simultaneously, and in particular the latter seems difficult to reconcile with the three former. FAO, however, promotes integrated foodenergy systems (Bogdanski et al. 2011), which makes frequent references to Brazil, including Brazil's processing flexibilities in producing either food (sugar) or fuel (ethanol), depending on the overall supply and market conditions.

This chapter analyzes Brazil, primarily as its efforts towards enhanced food production has been widely endorsed simultaneously as the human right to food has been strengthened, both through legal amendments and specific programmes. Brazil's policies are referred to when other states' agricultural and social policies are reviewed (Economist, 2011a; see also 
Economist, 2010a). At the same time, the expansion of agriculture has taken place in a way that severely threaten vulnerable ecosystems and indigenous peoples, also outside of the Amazon. The overall question for the chapter can be formulated as: "To which extent are the Brazilian policies for enhanced food production based on a human rights approach and to which extent is the overall Brazilian agricultural strategy recommendable to other developing countries?"

On this background, Brazil's policies are analyzed in light of requirements of international human rights treaties and national legislation. Relevant human rights provisions are interpreted in light of "any subsequent practice in the application of the treaty which establishes the agreement of the parties regarding its interpretation", as specified by Article 31.3(b) of the Vienna Convention on the Law of Treaties (United Nations, 1969).

The chapter will proceed as follows. First, the specifics of the three Brazilian agricultural models will be outlined, and the specific measures to promote them will be analyzed. Then, there will be an outline of the relevant legislation in Brazil, both concerning food production, fuel production and land issues. These laws will be seen in relation to relevant provisions from the International Covenant on Economic, Social and Cultural Rights ('ICESCR', United Nations, 1966a), which is the international treaty that recognizes both everyone's human right to food and peoples' rights to natural resources, and prescribes specific measures relating to food production, in Articles 1 and 11, respectively. Relevant clarifications have been done in General Comment 12 (CESCR, 1999) and in Voluntary Guidelines to Support the Progressive Realization of the Right to Adequate Food in the Context of National Food Security ('Voluntary Guidelines') (FAO, 2004). Finally, the negative consequences of the rapid growth of the Brazilian agricultural area will be reviewed, based on an assessment of the availability of arable land, forests and water, and the livelihood of indigenous peoples living outside of the Amazon.

\section{Brazil}

This section will map the central characteristics of Brazil, starting with an outline of the most pertinent concerns in the Brazilian agriculture, emphasizing the tensions between agricultural expansion and forest preservation, before moving on to a description of the three agricultural models that are found in Brazil. The most relevant legislations will be presented, first applying to agriculture and forests and then to the three agricultural models.

\subsection{Agricultural expansion in Brazil}

The Brazilian dilemmas are related to several facts. First, the inherited agricultural model is one in which the inequalities in land ownership is one of the most unequal in the world. This reflects a historical pattern of unequal distribution that no Brazilian government has been able to change; the Gini coefficient for land distribution was 0.857 in 1996 and 0.872 in 2006 (IPSNews 2009). It must, however, be recognized that the Gini coefficient regarding income distribution has been reduced from 0.607 in 1998 (CIA Fact Book) to 0.554 in 2008 (Sua pesquisa (no date)). Second, the most profitable and productive crops are plantation crops, most notably soy, sugarcane and palm oil. Third, increased mechanization of plantations will make much manual labor abundant, hence creating social insecurity. Fourth, while Brazil has available degraded and underutilized land, the pressure on original forests in the Amazon and other vulnerable biomes continues and policies for restricting 
agricultural use of these areas are not efficient, leading the authors to observe: "Public and private sector players in Brazil and neighboring countries now recognize that agricultural investment and expansion pose serious environmental challenges" (Deininger and Byerlee, 2010, xxix).

Moreover, deforestation has also been a concern for the Committee on Economic, Social and Cultural Rights (CESCR), recommending Brazil to "take the necessary measures to combat continued deforestation in order to ensure the effective enjoyment of economic, social and cultural rights, especially by indigenous and vulnerable groups of people" (CESCR, 2009, para. 26). This was actually the only paragraph among the CESCR's concerns which addressed food, which might be interpreted to imply that the CESCR did not view other aspects of Brazil's policies in the realm of food as equally critical for realizing the right to food in Brazil. Among the 'positive aspects' of Brazil's policies, the National School Food Programme is explicitly referred to (ibid, paragraph 3(d)).

The United Nations' Special Rapporteur on the right to food has stated that he "was impressed by the level of commitment of Brazil..." (Special rapporteur on the right to adequate food, 2009a, paragraph 32). The same Special rapporteur has recently addressed issues relating to land acquisition $(2009 \mathrm{~b}, 2010 \mathrm{~b})$ and the potentials of agroecology and the productivity gains by investing in small-scale agriculture (2010a). These approaches might seem to be at odds with the prevailing perception of the form of agriculture practiced in Brazil. The perception is that the Brazilian agricultural model is characterized by large units, high mechanization and monoculture.

\subsection{Three agricultural models}

While Brazil's diversity makes it difficult to make adequate categorizations, it is nevertheless possible to identify three agricultural models: agroindustry, family farming, and traditional harvesting and low scale-agriculture.

Agroindustry dominates in terms of area, covering approximately $3 / 4$ of all agricultural area in Brazil (Brazilian Ministry of Agrarian Development, 2009, 4) and representing 62 per cent of (registered) gross production value (ibid, 5). The average size of agroindustrial units, as reported in the 2006 Agricultural and Livestock Census, was 309.18 ha (ibid, 5). Overall agricultural policies are implemented by the Ministry for Agriculture, Livestock and Food Supply (MAPA). Much of this production is exported. Agricultural exports represent 35 per cent of Brazil's export earnings, and Brazil is the world's largest exporter of ethanol, sugar, coffee, chicken and beef - and the second largest exporter of soy. This is also the result of agricultural scientific efforts, primarily Embrapa (Brazilian Agricultural Research Corporation), which has resulted in an increase of average yield per hectare from $1528 \mathrm{~kg}$ in 1990 to $2850 \mathrm{~kg}$ in 2006 (Embrapa Agrienergy (no date)).

Family farming is crucial for domestic food security. Moreover, family farms represent 84.4 per cent of all (registered) farms (Brazilian Ministry of Agrarian Development, 2009, 4). The number of units has increased by approximately 10 per cent from 1996 to 2006, to more than 4.5 million (ibid, 10). The distinction between a family and a non-family farm is four fiscal units. The size of one fiscal unit varies according to agricultural conditions (National Institute for Colonization and Agrarian Reform (INCRA), 1980) and four fiscal units can represent anything between 20 and 440 ha. Hence, in some parts of the Amazon, a farm can 
be more than 400 ha and still be recognized as a family farm. In order to promote family farming, a separate Ministry for Agrarian Development (MDA) was established during the Cardoso Government, and the National Family Farming Program (PRONAF) has been in operation since 1995. PRONAF has several components, like the More Food Program, which has improved access to credit for the purchase of agricultural technology and equipment.

Finally, traditional agriculture and harvesting has also been promoted. The Brazilian government acknowledges that traditional communities, being both indigenous peoples and quilombolas (descendents of slaves) live in an area covering almost one quarter of Brazil (Government of Brazil, 2010). The total number of persons belonging to indigenous peoples is estimated to be 700.000. The number of persons belonging to quilombola communities is approximately 2 million, and there are also other traditional communities (Santilli, 2009, 191), but only indigenous and quilombola communities are entitled to collective land rights. Presently, 1711 quilombola communities are recognized (Fundação Cultural Palmares, 2011). By 2011 there were 343 areas for indigenous communities and 87 qiulombola territories which were registered (International Labour Organization (ILO), 2011, 790), but this does not imply full regularization and titling. The process on land demarcation is a potentially very long and complex one, and consists of four phases: Identification or delimitation (by the National Indigenous Foundation (Funai); declaration (by Ministry of Justice); demarcation (boundaries are clearly marked in the terrain); homologation (by the President) (Brazil, 2008, 20, note 11). Specifically on food production, Embrapa has initiated more than 20 projects - in coordination with Funai - to seek to improve the productivity of indigenous peoples' agriculture. Moreover, the Ministry for Social Development and Combat of Hunger (MDS) - by social safety programmes - seek to enhance the food security among indigenous peoples.

In summary, while the agroindustry is prevailing and will continue to expand, it must also be acknowledged that the Brazilian authorities have sought to strengthen also the two other agricultural models. This is a challenge to Paul Collier, who sees large-scale industrial agricultural as the only solution to the world's hunger crisis (Collier 2008). It is therefore reasonable to state that Brazil has a comprehensive approach towards agricultural productivity in general, but also that there is almost a separation between the various agricultural models, illustrated by the fact that they sort under different ministries.

As the general obligation provision of the ICESCR specifies "the adoption of legislative measures" (ICESCR, Article 2.1), it is highly relevant to review relevant Brazilian legislation, applying to each of the three models.

\subsection{Legislation applying to agricultural expansion vs forest preservation}

As we saw above, the CESCR has expressed concerns for deforestation in Brazil. The basis for this concern is that those persons and communities which depend on the harvesting from the forest will be negatively affected by the conversion of forests to other uses. Hence, before analyzing legislation applying specifically to the three agricultural models, the most relevant laws regarding forests will be briefly analyzed.

Specifically on the Amazon, Act 11.952 of 2009 regularized properties which had been occupied by farmers before 2004, even if the occupations and subsequent utilization of the relevant property were illegal. If the property is smaller than 100 hectares, it will be given 
for free, and if it is between 100 and 1500 hectares it will be sold at subsidized rates. Larger properties than 1500 hectares would have 'only' 1500 hectares regularized. As stated in a World Bank study "this law could encourage speculative land occupation and deforestation in expectation of future regularization" (Deininger \& Byerlee, 2010, 121).

Applying to the whole of Brazil, amendments to the Forest Act (Codigo Florestal) were approved by the Lower House in May 2011. The basic elements of these amendments are to provide for an amnesty for forest clearance beyond what is allowed for each property - but only for cutting before July 2008 - and to reduce the proportion of each property that must be preserved. Increased deforestation as a result of this legislative proposal has been reported by the Brazilian Environmental Agency (IBAMA) (The Rio Times 2011). The proportions under the current Act are $80 \%$ in the biological Amazon; $35 \%$ in the Cerrado within the legal Amazon (9 states); and $20 \%$ in rest of Brazil. It is hard to get figures on the number of persons who have been accused of violating the Forest Act by clearing more forests than permitted, but the mere need for an amnesty for those involved in illegal clearance shows that the law enforcement is not effective.

In this context of facilitating deforestation, a reference can be made to Article 186 of the Brazilian Constitution, which specifies the social function of rural land, with four requirements that must be met simultaneously: "I. rational and adequate use; II. adequate use of available natural resources and preservation of the environment; III. compliance with the provisions which regulate labor relations; IV. exploitation which favors the well-being of the owners and workers." While the emphasis is on the use of the land, the social function cannot be met by removing forests, as this does not meet requirement II.

Cattle raising is the type of agriculture which is most threatening to the vulnerable biomes in the Amazon and the Cerrado (south and east of the Amazon) for the time being. This form of agriculture has low productivity per hectare, but is a most effective way of gaining control over land. Moreover, the Rural Real Estates Act No. 4,504 of 1964 introduced the phrase temporary possession ('posse temporários da terra'), enabling anyone to obtain a title of land simply by starting to use this land. Article 97.II specifies that anyone who has served for a year the claimed land can get a title to this land. The 1988 Constitution, on the other hand, establishes in Article 191 a higher requirement of the duration of use:

The individual who, not being the owner of rural or urban property, holds as his own, for five uninterrupted years, without opposition, an area of land in the rural zone, not exceeding fifty hectares, making it productive with his labour or that of his family, and having his dwelling thereon, shall acquire ownership of the land.

The difference between the two provisions is that the former requires purchase ('adquirir'), while the latter simply says that five years uninterrupted an unopposed use enables one to acquire the land. The whole process of obtaining documents is characterized by nontransparency, fraud and legal uncertainty. According to a study, private possession of 100 million hectares of land in the legal Amazon - which represents 509 million hectares - is based on fraudulent documents (Wilkinson et al., 2010, 15; quoted in Sauer and Pereira Leite, 2011, 4).

The vanguards in any land occupation activities are the so-called 'grileiros' or land grabbers, but these are not the only actors driving the Brazilian deforestation (Fearnside 2008). The name grileiros is derived from an insect that can do damage to paper documents so that 
they appear older than what they actually are, in order to facilitate the falsification of land title documents. It is fair to say that the grileiros are inadequately regulated, and that even violence and murder committed by them is underinvestigated and unpunished.

\subsection{Legislation applying to the three agricultural models}

Regarding the agro-industry model it is also relevant to notice that the social function of rural land provision of Brazilian Constitution has been a basis for a program of expropriation of unproductive lands, transferring some of it to landless persons and communities. There will be different opinions on how comprehensive this policy of land distribution policy is. As we have seen, the Gini coefficient for land distribution in Brazil illustrates the skewed distribution, and INCRA finds that 120 million hectares - or 27 per cent of all agricultural lands in Brazil - is unproductive (Sauer and Pereira Leite, 2011, 5). Finally, of relevance for understanding how Brazil's authorities facilitate large-holdings, Brazilian law has never defined any maximum size for properties.

Addressing family farms, several laws have recently been adopted. These laws provide for enhanced public purchases from family farms, including to the school feeding programme (PENAI; law 11,947 of 2009) and the national biodiesel programe (PNPB; law 11,097 of 2005). The latter establishes a 'social fuel seal', given to purchasers that buy a given share of their total input for biodiesel production, varying between 15 and 30 per cent, depending on the region. Processors without this seal will not be allowed to participate in the regular auctions for biodiesel, where $80 \%$ of the national demand is purchased at slightly higher prices. Moreover, a Family Farming Act (11.326 of 2006) has been adopted, as specified by Decree 6.882 of 2009 .

The policy for promoting purchase from family farms within the national biodiesel programme was a response to the situation in the bioethanol sector, which is dominated by sugarcane large-holdings. The national biodiesel programme sought to facilitate the gradual expansion of family farming and avoid that the introduction of biodiesel resulted in more plantations and monocropping. While the volume targets for the purchase have not fully been met on a national level, it is still possible to talk of a gradual integration of family farming into the national biodiesel programme. Section 4 will analyze in greater detail whether this shift represents a challenge for the production of food and food security.

Also for the traditional model of agriculture, several laws have been enacted recently. The seed law 10.711 of 2003, as specified by Decree No. 5.153 of 2004, exempts traditional cultivars from the requirements in Article 11, saying that "production, processing and marketing of seeds and seedlings are conditioned to prior registration" in the National Register for Cultivars (RCN), and Article 48 prohibits any restrictions on the distribution and exchange of such traditional cultivars.

In order to reduce the incentives for deforestation, the sociobiodiversity programme of the National Food Supply Company (Conab) includes the 'Policy of Minimum Guanteed Price', established by law 11,775 of 2008, applying to everyone who harvests traditional food from the forests. By ensuring such a minimum price it is believed that persons are more motivated to preserve and harvest from the forests than to destroy and convert the forests. This Act must be considered to be a good example of how Brazil seeks to promote social inclusion and reduce the incentives for deforestation by those living in or from the forests. 
There are, however, serious problems facing many of the indigenous peoples living outside of the biological Amazon, as their traditional territory has been subject to agricultural expansion, and if territories have been demarcated at all, they are too small to maintain an adequate standard of living. This is despite efforts by Funai and the Federal Prosecution Office to strengthen the land rights of indigenous peoples in accordance with Articles 231 and 232 of the Brazilian Constitution, the latter with a mandate in Article 129.V of the Constitution to defend the rights and interest of the Indian populations.

While a full review of all relevant legislation in Brazil is obviously not possible, this section has highlighted the laws which are believed to be the most relevant in order to understand the Brazilian agricultural system, and also provided some insights into the context in which they operate. The section has not addressed the laws which regulate the agricultural cooperatives, which are important, in particular in the South, and neither has the section addressed the laws relating to the marketing of agricultural products. It is found that the laws have not been adequately effective in order to ensure that forest land is not converted, or that non-productive land is effectively used, but that they have been used to promote family farming and traditional harvesting and seed exchange.

\section{Substantive human rights and human rights principles}

Before introducing the most relevant human rights for the purpose of the analysis, a brief outline of the most central approaches for understanding human rights, particularly economic, social and cultural rights, will be provided. The most innovative aspect of this section is nevertheless believed to be the analysis of human rights principles, which are highly relevant for assessing the overall conduct of the relevant policies, and hence the quality of the day to day policies.

\subsection{Approaches for understanding economic, social and cultural human rights}

While most central characteristics apply to all human rights, and there should be no artificial distinction between the various types of human rights, certain approaches have been developed that apply particularly to economic, social and cultural rights. These approaches have been introduced by legal scholars in order to get a better understanding of primarily the state obligations derived from the economic, social and cultural rights. These approaches have subsequently been applied by UN human rights bodies, international organizations and states.

The typology of respect, protect and fulfill (facilitate and provide) is the most frequently applied (Eide 2007). Under this approach, the state shall avoid interfering in the enjoyment of any of the recognized rights, but also preventing others' interference. The state is, moreover, obliged to undertake measures in all relevant policy spheres for the effective realization of the human rights, and - if the situation requires - ensure that the necessary goods and services are provided to those who have no other opportunity to exercise the human rights by their own efforts. No provision of such goods and services should continue beyond what is necessary to ensure enjoyment of human rights (CESCR, 1999, paragraph 39).

As specified by Welling (2008, 950-953), one can also apply a core content approach, seeking to identify the core of the specific human rights provisions (CESCR, 1991, paragraph 10), or the analytical categories approach, focusing on structure, process and outcome. Hence, an 
adequate understanding of the societal context affecting the realization of the human rights, and the conduct that is applied for the realization of human rights are most relevant for the actual realization of human rights.

When analyzing the right to food as a social human rights, it is relevant to note how the CESCR understands the realization of - and the obligations deriving from - this and other rights recognized in the ICESCR, stating that:

"the obligation differs significantly from that contained in article 2 of the International Covenant on Civil and Political Rights ['ICCPR', United Nations, 1966b] which embodies an immediate obligation to respect and ensure all of the relevant rights. Nevertheless, the fact that realization over time, or in other words progressively, is foreseen under the Covenant should not be misinterpreted as depriving the obligation of all meaningful content (ibid, paragraph 9 (extract)."

The CESCR itself identifies two obligations which are of immediate effect, namely to ensure that the rights are exercised without discrimination and to take "deliberate, concrete and targeted" measures for the realization of the ICESCR (ibid, paragraphs 1 and 2). These two obligations of immediate effect can be read out of the ICESCR Article 2.2 and Article 2.1, respectively. We will come back to these provisions below.

\subsection{Substantive human rights}

While criticisms are raised against the human right to food (Economist, 2010c, 2011a), this chapter will not be used to discuss whether the right to food actually exists. The strong and unanimous endorsements by various bodies of the United Nations of the reports by the Special Rapporteur on the right to food (Special rapporteur 2009b, 2010a, 2010b), confirm that the states consider the right to food to be a human right. Both Article 11.1 and Article 11.2 of the ICESCR recognize the right to food, the latter specified as the right to be free from hunger. In brief terms, the right to be free from hunger can be understood as the core content of the right to food. As Article 11.2 is more comprehensive, the emphasis will be on this provision, which is also justified by the simple fact that hardly any states can claim that none of its inhabitants are facing hunger, hence claiming that the corresponding obligations are not applicable.

Article 11.1 embeds the right to food in the right to an adequate standard of living, including "the continuous improvement of living conditions." It is reasonable to state that while the latter element of the right applies generally, the obligations derived from this right must be particularly observed with due concern for the most marginalized persons (Haugen, 2007, 123).

Article 11.2 has two subparagraphs; the latter applying to international trade (Haugen, 2009, 271-271) and the former specifying that the states shall take measures which are needed:

To improve methods of production, conservation and distribution of food by making full use of technical and scientific knowledge, by disseminating knowledge of the principles of nutrition and by developing or reforming agrarian systems in such a way as to achieve the most efficient development and utilization of natural resources.

The qualification in the introductory part of Article 11.2 saying that the measures are 'needed' cannot be interpreted to reduce the emphasis of the mandatory term 'shall'. Both 
the fact that the listed measures fall within highly relevant policy spheres, the fact that only one state, Pakistan, abstained from the vote when Article 11.2(a) was adopted (Haugen, 2007,128 , note 64 ), and the fact that the drafters decided - after a discussion - not to include the term 'necessary measures' in the introductory paragraph of Article 11.2 (ibid, 128-129) demonstrates that the states cannot avoid considering these measures.

A previous chairperson of the CESCR has identified the structure of this provision in the following manner, after acknowledging that the paragraph "is a relatively confused and by all means no all-embracing mixture of means and ends" (Alston, 1984, 23). He finds that in Article 11.2(a) there are three objectives:

1. to improve methods of food production;

2. to improve methods of food conservation;

3. to improve methods of food distribution.

4. Moreover, the following measures are identified: making full use of technical and scientific progress;

5. disseminating knowledge of the principles of nutrition;

6. developing or reforming agrarian systems.

Furthermore, the final phrase 'in such a way as to achieve the most efficient development and utilization of natural resources' applies to the whole paragraph, and not only to the last part of it (ibid, 35).

Three elements of this paragraph will now be analyzed: the relationship between improved production and improved distribution; the reform of agrarian systems; and the development and utilization of natural resources.

\subsubsection{The relationship between improved production and improved distribution}

First, while realization of the right to food by necessity depends on the fact that enough food is actually being produced, the relationships between food production and consumption is not necessarily straightforward, even if one does not consider agricultural exports and imports. The CESCR addresses these complex relationships by introducing the terms availability and accessibility. Improved methods of food production - in other words increased food availability (CESCR, 1999, paragraphs 8 and 12) will be beneficial for the realization of the right to food provided that the most relevant conditions are in place in order to facilitate food accessibility (ibid, paragraphs 8 and 13). In addition to food prices, these conditions relate to ownership structures, or in the words of the CESCR "acquisition pattern or entitlement", identifying a particular vulnerability among "indigenous population groups whose access to their ancestral lands may be threatened" (ibid, paragraph 13). The Brazilian Constitution recognizes indigenous peoples' property rights in Articles 231 and 232.

Moreover, measures for enhanced ecological sustainability, better infrastructure, market systems and adequate public extension services in order to provide new and improved seeds, are also crucial for food availability and accessibility. Much more emphasis should be placed on the adequate distribution of food-producing resources (Haugen, 2007, 140), including by various forms of participatory breeding involving the farmers themselves. Stated differently, by improving food production in a socially inclusive manner, this will 
enhance the food self sufficiency of local communities. This will in turn reduce vulnerabilities and dependencies. It must be noted, however, that study by the International Fund for Agricultural Development (IFAD) also finds that " $[w]$ here farmers are consulted about their priorities, they often select priorities other than yield" (IFAD, 2001, 136).

No specification of what is understood by the phrase "improve methods of production ... of food" is provided by General Comment 12, including which food producing technologies that are most appropriate, but rather states the obvious that production of food is crucial for the food system (CESCR 1999, paragraph 25). Hence, it does not specify how new agricultural products are to be developed and made available. Improved agricultural productivity is an obvious objective for all involved in food production, and the yield gap identifies the gap between the current and the potential yield. The yield gap differs considerably between various regions (Neumanna et al., 2010). When identifying policies that could close the yield gap, FAO's High Level Panel of Experts on Food Security and Nutrition identified four interventions: revitalized extension services, improved markets, strengthened property rights and enhanced infrastructure (FAO, 2011, 25). Obviously, all of these measures require high-quality public measures, relating to legislation, institutions and budget priorities. It is fair to say that Brazil is relatively advanced in these sectors, illustrated by the expansion of the MDA's National Rural Extension Policy, initiated in 2003 (Special Rapporteur on the right to food, 2010a, 15).

\subsubsection{Reform of agrarian systems}

Reforming agrarian systems is the second element of ICESCR Article 11.2(a) to be analyzed, and applies to land reform and strengthened property rights. No serious attempt of clarifying this phrase is done in General comment 12, but "right to inheritance and the ownership of land and other property" is specified as elements of women's equal access to economic resources (CESCR 1999, paragraph 26; see also Voluntary Guidelines 8B). While property rights function differently in diverse socio-economic contexts, the following observations must be considered to apply across these different contexts:

"Vulnerable groups suffer most from a lack of property rights. Indigenous peoples are frequently victims of property discrimination; collectively held indigenous lands have often been declared public or unoccupied lands (and collectivity can be retained in formalizing property rights). Women, who constitute half of the world's population, own very little of the world's property - as little as two percent in some countries (Commission on the Legal Empowerment of the Poor, 2008, 36; see also Eide, 2009)."

We see that collective ownership is emphasized. In addition to the property rights to land, there must also be a regulation of the natural resources found on - and under - the land. In most states, mineral and other sub-surface resources are regulated differently from other resources, as illustrated by the Brazilian Constitution Article 231.3. Moreover, as seen in Section 2.2 above, the whole process of obtaining land ownership for indigenous communities in Brazil can be long and cumbersome, with possibilities for legally challenging each of the decisions in the various phases of the process.

The transfer of property rights from a community to an actor seeking to establish a development or investment project is also bound to be contentious. The basic approach as formulated in ILO Convention 169 concerning Indigenous and Tribal Peoples in 
Independent Countries ('ILO 169', ILO 1989) Article 6.1(a) is that any such transfer must only take place after a "through appropriate procedures, and in particular through their representative institutions..." (see also UN Declaration of the Rights of Indigenous Peoples ('UNDRIP'), United Nations, 2007, Article 18). What these 'appropriate procedures are, have been sought clarified. Two complaints against two of Brazil' neighbor states, Peru and Surinam, will be provided as examples. On the one hand, the Human Rights Committee, monitoring the ICCPR, "considers that participation in the decision-making process must be effective, which requires not mere consultation but the free, prior and informed consent of the members of the community" (HRC 2009, paragraph 7.6). Three terms are central: 'effective', 'free, prior and informed consent' (FPIC) and 'the members'. An analysis of FPIC will be undertaken in the following section; now the emphasis will be on the term 'members'. As applied by the HRC the term 'members' applies to everyone in the community, hence being a comprehensive approach.

While also emphasizing effective participation and FPIC, the Inter-American Court of Human Rights (IACHR) deviates from the HRC concerning the scope of participation. The IACHR has confirmed that the customary tradition of the relevant peoples must be decisive when determining what is effective participation (IACHR 2008, paragraphs 13, 19 and 26), implying that the state must consult with those representatives that the peoples themselves have chosen. This illustrates the distinction between effectiveness and representativeness. For indigenous peoples, it must be expected that the least influential in the community are also those who are most dependent upon natural resources, and have the highest overall vulnerability. This gives a basis for questioning whether an effective participation involving only those who are said to represent the respective peoples, is adequate and able to avoid future tensions with those claiming not to have been adequately represented.

\subsubsection{Development and utilization of natural resources}

The phrase "development and utilization of natural resources" must be understood in light of the emerging understanding of natural resources that has been witnessed the last decades, as also specified by the World Trade Organization's (WTO) Appellate Body in US Shrimps when clarifying the term 'exhaustible natural resources' (WTO 1998, paragraph 131). Hence, the utilization of such resources must take place in the context of the principle of sustainable development, implying that all decisions must be taken with due regard to how they affect nature and current and subsequent generations.

The term natural resources are also found in two other provisions of the ICESCR and ICCPR; both having an identical wording. First, common Article 1.2 reads (extract): "All peoples may, for their own ends, freely dispose of their natural wealth and resources..." An even stronger wording is found in Article 25 and Article 47 respectively: "Nothing in the present Covenant shall be interpreted as impairing the inherent right of all peoples to enjoy and utilize fully and freely their natural wealth and resources." By applying the term 'inherent' this must be understood to imply that the right cannot be traded away. The fact that the term 'peoples' includes indigenous peoples is confirmed by UNDRIP, Article 3.

Natural resources preservation is not addressed in detail in the CESCR's General comment on the right to food (CESCR 1999, paragraphs 12, 25, 26 and 27). As an example of a natural resource issue that has emerged recently and which has created tensions both within and 
between countries is how the decision-making process shall be conducted when concerning access to genetic resources and the subsequent sharing of benefits resulting from the utilization of these resources. The patenting of such resources is allowed by the International Treaty on Plant Genetic Resources for Food and Agriculture ('ITPGRFA', FAO, 2001a), Article 12.3(b), provided that these resources have been subject to a changed 'form'; as emphasized by numerous declarations by representatives of industrialized countries delivered after the adoption of the ITPGRFA (FAO 2001a). While the ITPGRFA is not a human rights treaty, farmers' rights are recognized in Article 9. Protection of traditional knowledge and rights to participate in decision-making and benefit-sharing are components of farmers' rights, and these elements are also emphasized in the Voluntary Guidelines (FAO 2004, Guideline 8D).

\subsubsection{Summary, emphasizing the international and social dimension}

The above analysis shows that the realization of the right to food by necessity must take into account a wide range of issues. While some of them are obviously costly, such as the extension services and improvements in infrastructure, it is also highly relevant to note that the drafters foresaw that realization of the right to food depending upon international assistance. The general obligation provision of the ICESCR, Article 2.1, emphasizes international assistance and co-operation, implying that international cooperation and assistance is central for the realization of all the recognized rights of the ICESCR, but there are explicit references to international assistance in both Article 11.1 and Article 11.2. Hence, it is reasonable to state that international assistance is particularly important for the realization of the right to food.

Particularly for the purpose of developing and providing new varieties, the international research cooperation has been successful. The rate of return from investments in national agricultural research services (NARS) is 60 per cent, and from investments in international agricultural research centers (IARC) is more than 70 per cent (von Braun et al., 2008, 10; see also World Bank, 2007, 6). Any developing country should facilitate the cooperation with these centers and provide for interaction between farmer associations and breeders and these centers.

Finally, general subsidies have been found to be less effective compared to specific provision of specific goods and social services (Special Rapporteur on the right to food 2010a, 17). Moreover, several measures can be taken which are not in themselves very costly. This includes the adoption of an adequate legislation for ending discrimination in ownership of land and other resources, or in the school system. Such measures will enhance participation and empowerment. One study finds that by ending discrimination in the school system, which is a central task for public authorities, malnutrition among children is reduced by 13.4 per cent in South Asia and 3 per cent in Africa (Smith et al. 2002), and another study finds that it leads to an increase average in economic growth with 0.4 to 0.9 per cent (Klausen 2002). This clearly shows that conscious social policies are integral to any food and food production policy.

\subsection{Human rights principles}

No decision by any intergovernmental body has defined or exemplified the term 'human rights principles'. One of the first appearances of the term is in General Comment 12 (CESCR 
1999, paragraph 21), listing the following: dignity (ibid, paragraph 4), non-discrimination (ibid, paragraph 26), accountability, transparency, people's participation, decentralization, legislative capacity and the independence of the judiciary (ibid, paragraph 23). Subsequently, the socalled 'Common Understanding' among UN agencies gave a central role to human rights principles in the context of a human rights approach to development cooperation (United Nations Development Group, 2003; see also Haugen, 2011).

FAO has identified the following human rights principles: participation, accountability, nondiscrimination, transparency, human dignity, empowerment and the rule of law (FAO, 2007, 2). These are derived from human rights provisions and apply to all forms of conduct, and apply to development or investment actors, in addition to states (Haugen, 2011). By applying the term 'include' before this listing, FAO has open up for possible additions to this list. Both Eide $(2009,28)$ and Ssenyonjo $(2009,147)$ have applied FAO's seven human rights principles, but adding others, namely 'good governance' and 'monitoring', respectively. Good governance is the result of the careful observation of the human rights principles, while monitoring is the practical tools to ensure and improve compliance. Therefore, it is justified to keep the seven human rights principles as specified by FAO.

There will now be a brief outline of the seven human rights principles, specifying their application in the context of overall policies for food production, with examples taken from Brazil. As the dealing with indigenous peoples are likely to present the largest asymmetries, the quality of the conduct is even more crucial compared with dealing with actors and communities that are more equal in terms of power. The review will start with the most basic principles.

Dignity is the foundational basis for the constituting of both human beings and human rights. Dignity can also be applied in order to assess certain policies. As the life fulfillment of indigenous peoples in Brazil are so closely related to their territorial belonging, it cannot be considered controversial to identify the territorial expansion of agriculture which considerably reduces the living space of indigenous peoples to be a systematic challenges to human dignity of many in Brazil's indigenous peoples. During a research field trip to Brazil, including Mato Grosso do Sul in March and April 2011, the author was also informed by a representative of the agroindustry that the best way to promote the dignity of indigenous peoples was to get employment, and the author agrees that each person must be free to integrate in the larger society without being ostracized from one's indigenous community.

Four UN Special Rapporteurs, including the Special Rapporteur on the right to food, have addressed the situation for the Guarani Kaiowá in Mato Grosso do Sul (Special Rapporteur on the situation of human rights and fundamental freedoms of indigenous peoples, 2008, 1921; see also Special Rapporteur on adequate housing as a component of the right to an adequate standard of living, 2010, paragraph 60). While acknowledging the stalemate these reports refer to, work is undertaken: six 'technical groups' have been mandated by Funai to identify Guarani Kaiowá territories in Southern Mato Grosso do Sul, and their reports are expected by the end of 2011. It must in this context be taken note of the Brazilian Constitution's emphasis on the maintenance of cultural diversity in Article 215 and 216, and the UNESCO Convention on the Protection and Promotion of the Diversity of Cultural Expressions, particularly Article 2.3, which links cultural diversity and human dignity.

Non-discrimination is about like treatment of like cases and unlike treatment of unlike case. Hence, to give preferential treatment to persons from certain categories which are 
substantively underrepresented or marginalized is not in violation of the non-discrimination principle - as long as this treatment ends as soon as substantive equality is achieved. Moreover, the non-discrimination prohibition applies generally to any "field regulated and protected by public authorities" and not only to the specific human rights which are recognized by the human rights treaties (HRC, 1989, paragraph 12). As persons from indigenous peoples are relatively less able to defend their rights, it is must be considered to be fully in line with the principle of non-discrimination that the Federal Prosecution Office takes a pro-active approach in accordance with the mandate given to it in Article 129.V of the Brazilian Constitution. The Funai mapping referred to above has been moving forward based on a 2007 agreement between Funai and the Federal Prosecution Office.

Rule of law is a comprehensive human rights principle, and encompasses the overall effectiveness of the judicial system and independence of judges and lawyers. It is also about applying the same standards irrespective of social, institutional and other weaknesses prevailing in certain regions. While it is difficult to single out Brazil from other states in South America, the relatively stronger ties between the various political and economical elites is a constant challenge to the quality of the court system's equal treatment of persons with and persons without formal and informal power. It must be acknowledged, however, that Brazilian courts are not necessarily acting in a restrictive manner. The Special Rapporteur on indigenous peoples observed that the Supreme Federal Tribunal's 2009 decision in the Raposa Serra do Sol case - which was exactly about the demarcation of an indigenous territory - found that the Tribunal went "far beyond the specific wording of the Constitution or of any applicable legislation..." (The Special Rapporteur on the situation of human rights and fundamental freedoms of indigenous peoples 2009, paragraph 39). This is an indication that rule of law can be operationalized strictly, as the requirement that any decision must only be based in the applicable legislation, or less strictly, where concerns beyond the mere wording of the legislation is influencing the interpretation.

Accountability is distinct from responsibility in that the former is based on external standards and external sanctions mechanisms to be applied in cases on non-compliance. Accountability is closely related to the quality of institutions, and how these institutions are able to operate independent of the prevailing power structures. The Special Representative on business and human rights, in a study of human rights impact assessment says that indigenous customary laws and traditions are among the legal and regulatory requirements to be catalogued before any intervention starts (Special Representative of the SecretaryGeneral on the issue of human rights and transnational corporations and other business enterprises 2007, paragraph 23). In order to identify appropriate mechanism for finding and punishing violations of indigenous customary law, the (non-binding) UNDRIP contains certain relevant provisions (UN 2007, paragraph 27 and 28).

Transparency is about providing information about any relevant decision is a timely and appropriate manner. As an example, any process about investment decisions needs to be as transparent as possible. Not only documents and maps, but also models and physical places need to be made visible. The FPIC process (see section 3.2.2) is about giving consent based on a process free of compulsion or illegitimate rewarding, and where scope of the final project as well as both the negative and positive consequences are outlined to all the affected parties. The term 'process' indicates that one meeting is inadequate for the FPIC to have been undertaken appropriately. 
Participation is facilitated by appropriate transparency. As noted in section 3.2.2, it can be asked whether the understanding of ILO 169 Article 6.1(a) ('in particular through their representative institutions') and UNDRIP Article 18 ('through representatives chosen by themselves in accordance with their own procedures') and the IACHR's emphasis on 'effective participation' is adequate in order to comply with the overall understanding of the human right to participation. ICCPR Article 25(a) specifies a human right "[t]o take part in the conduct of public affairs, directly or through freely chosen representatives." Hence, we see that participation through representatives and direct participation are made equal. On the other hand, the emphasis on the indigenous peoples' own procedures is fully legitimate, as there might be individuals and groups of individuals in any community who claims to speak on behalf of the community, when they are in fact speaking only on behalf of themselves. Still, the author is convinced that broad participation at an early stage of a decision-making process will reduce the number of conflicts at the later stages.

Empowerment is in many ways the outcome of gaining experiences with participation. Empowerment is also a precondition for the actual participation. The most elaborate understanding of empowerment in any human rights treaty is found in the ICESCR Article 13.1, recognizing the right to education, which

...shall be directed to the full development of the human personality and the sense of its dignity, and shall strengthen the respect for human rights and fundamental freedoms. They further agree that education shall enable all persons to participate effectively in a free society...

Hence, the development of the human personality and the sense of its dignity are interrelated, and are overall objectives of education. An inclusive educational system is not achieved in Brazil. Moreover, despite traditions for organizing among workers in general in Brazil, and recent efforts to improve the overall conditions for the agricultural workers such as the 2005 National Pact for the Eradication of Slave Labour, which has been signed by 250 companies, associations and NGOs, and the 2009 National Commitment to Improve Labour Conditions in Sugarcane Production, which has been signed by 331 companies - it is fair to say that there is a lack of empowerment among large segments of Brazil's agricultural workers. Moreover, in order to protect the cultural diversity of Brazil's indigenous peoples, the authorities have adopted both a paternalistic approach and a form of segregation, by confining indigenous people to certain areas and not allowing non-indigenous persons to enter these areas. This can be partially explained by the relative weakness of many indigenous peoples in Brazil.

In summary, human rights principles are relevant and can serve to strengthen the implementation of the substantive human rights. Human rights principles should never operate alone, but only in conjunction with the substantive human rights. Attempts of introducing principles in isolation from human rights are deemed to provide weak and unaccountable results. Moreover, as the review has illustrated, it is necessary to have an appropriate understanding of the structure within which the human rights are to be exercised (Welling 2008), 950-953). This obviously includes an analysis of prevailing power structures. In an otherwise critical article about the right to food the Economist admits that a human rights approach can "force the state to perform where it has previously failed, and start to overturn the traditional power structures..." (Economist, 2010c; see also Economist, 2011a). Improving public conduct and constraining power abuse are elements of a human rights based approach. 


\section{Particular human rights challenges in Brazil}

Certain challenges relating to food production are particularly relevant in Brazil. This section cannot do full justice to the magnitude of challenges facing Brazil's agriculture, but three issues have been identified, namely land reform, biofuel expansion, and the management and appropriation of genetic resources. These are also issues that are considered to be of most relevance for the overall theme of this chapter, identifying how human rights could guide food production in Brazil.

\subsection{Land reforms}

The human right to food was included in the Brazilian Constitution in 2010, as part of the social rights provision of Article 6. Moreover, Article 5.3 says that "international treaties and conventions on human rights ... have equal value as constitutional amendments." Hence, international human rights law must be presumed to influence public policies in Brazil. Based on CESCR's concerns, outlined in Section 2.1 and the review of the relevant forest legislation in Section 2.3, as well as the lack of legislation to limit the maximum property size, there are several issues within land reform that are contentious.

Brazil has a substantial land potential, as illustrated by it being ranked as number 14 among all states regarding 'land resource potential and constraints' (FAO, 2000, 112). The country ranking is based on seven variables: potential arable land as a percentage of total land area, deserts and drylands, steeplands, land degradation severity, land presently cultivated (actual arable land) per capita, cultivated land as a percentage of potential arable land, and population increase (percent per year). 10 per cent of the arable land of Brazil is currently under permanent crops, which indicates that there is a potential for agricultural expansion.

Among the most substantive land reforms undertaken during the last decades is the Cédula da Terra project, a World Bank-supported negotiated land reform program in four states in the North-East region in addition to Northern parts of Minas Gerais. It lasted from 1997 to 2002. According to a critical study (Sauer, 2006), the program suffered under substantial weaknesses, such as lack of participation in the process, and lack of relevant technical assistance, with the result that many became indebted. The disapproval of the overall directions of the Cédula da Terra is illustrated by the fact that a network 'National Forum for Agrarian Reform and Rural Justice' presented a case before the World Bank's Inspection Panel, which rejected the case (Sparovek \& Maule, 2009, 297).

The Special Rapporteur on the right to food distinguishes between two models of security of tenure, one market-based titling process and one seeking to broaden entitlements of individuals and communities (Special Rapporteur, 2010b, paragraph 21). The former can result in confirmations of unequal distribution of lands (ibid, paragraph 17). Not surprisingly, the Special Rapporteur argues in favor of strengthening of customary land tenure systems (see also Commission for the Legal Empowerment of the Poor, 2008).

As Brazil have relatively better institutions operating in land management, the country is less likely to become subject to speculative land acquisition of the kinds reported in the Economist (2011c, 57-58). The report is partly based on Deininger and Byerlee (2010) which found that actual farming had only started on 21 per cent of the properties that had been sold or leased (ibid, xiv). Of great relevance is the fact that the Office of the Solicitor General 
(AGU) on 19 October 2010 issued Informed Opinion LA-01, which reregulated the process of land appropriation by foreigners in Brazil (Sauer \& Pereira Leite, 2011, 28). This was done by resuming Act 5709 of 1971, while affirming that this act must be accepted under the scope of the Constitution of 1988.

Negotiated land reforms were initiated by the successive Lula governments, and in 2008, Decree 6.672 was passed. It allowed agrarian reform to proceed in the absence of external funding. Moreover, the state-led agrarian reform based on expropriation of unproductive lands is continuing under different governments. While there are different views on the comprehensiveness of agrarian reforms, the clearest indication that the agrarian reforms have not had an adequate impact is the Gini coefficient for land distribution, being above 0.85 and unchanging.

\subsection{Biofuels expansion}

As we saw in Section 1, Brazil has emphasized food sovereignty in its 2006 law 11.346 on a 'National Food and Nutrition Security System (SISAN)'. The whole text of the relevant paragraph reads: "To attain the human right to adequate food, and food and nutrition security, sovereignty must be respected, and countries must be guaranteed the supremacy of their own decisions regarding food production and consumption." The policy area of biofuel expansion is exactly such an area where Brazil rejects the interference by external actors in its own policies, insisting that there is no conflict between biofuels expansion on the one hand and better food security on the other hand. There are several different definitions of food sovereignty contained in documents adopted by the food sovereignty movement itself (Haugen, 2009, 274-280). Rather than review these definitions, the analysis below builds on the relevant extract of the provision given in the Brazilian law, namely that 'countries must be guaranteed the supremacy of their own decisions regarding food production and consumption'.

Brazil is currently the only country in the world where biofuels represent more than 50 percent of all fuel, and the relevant actors say that its bioethanol production shall reach 70 billion liters by 2020, but the growth in production from 2008 to 2010 has been modest (Renewable Fuels Association, 2011). Most of this production is for the internal market. From 1 July 2007, there has been a 25 per cent mandatory blend of ethanol in fuel. As the biodiesel industry is of less magnitude and is more diverse concerning which crops that are available for processing, the emphasis of this section will be on sugarcane-based bioethanol. There will, however, also be a review of the policies to promote palm oil within the overall biodiesel policy.

Whether bioethanol expansion can be at the expense of the right to food is a contentious issue. Observing current global price and predicted future food availability impacts, the Economist - based on FAO estimates - noted: "Biofuels are an example of what not to do" (Economist 2011b). This general observation does not necessarily apply to each and every country where biofuels are produced. As noted in Section 4.1 above, there is land availability in Brazil, but the concern for vulnerable biomes, including the Atlantic Forest (Mata Atlantica) and the Cerrado, is most relevant to repeat in this context of biofuels expansion as part of the overall agricultural expansion (Deininger and Byerlee, 2010, xxix).

A study on the overall impacts of biofuels expansion in Brazil states: "The growth of sugarcane production for the production of ethanol could compete with the production of 
food" (Smeets et al., 2008, 793). After a further discussion of the current situation, the study, however, finds that "poverty is currently a major bottleneck for food security, much more than a lack of production means like land or labor due to the production of sugarcane" (ibid, 794). A similar finding is made by the NGO Reporter Brazil 2009: Brazil of Biofuels: Soybean, Castor Bean 2009, says on p. 8: "there are no conclusive elements to state that biofuel production is having an impact on food crops in Brazil..."

Hence, in principle, sugarcane expansion can take place without reducing the area for food production. As the expansion of sugarcane is planned to take place in those areas of Brazil which have the most fertile soil, this, however, should be a reason for concern in the longer term. Moreover, if the targets on biofuel blending in several countries - which are already very ambitious and relying on imports - are becoming even higher, this will necessitate new assessments. Finally, concerning food production, three general observations seem relevant.

First, acknowledging that Brazil does have considerable areas of unproductive land, degraded land and underutilized land on a national level does not imply that there will not be conflicts relating to land use on the local level. The focus for human rights is the vulnerable persons or communities that will be affected by the expansion of areas utilized by commercial and more powerful actors. Second, while Brazil has a diversity of agricultural production on the national level, this does not imply that monoculture in specific regions cannot be a problem, at least in the medium and long term. Third, notwithstanding the fact that Brazil can be considered as one national food market, food security in the various regions will be strengthened if there is an adequate diversity in food production in all regions. Adequate supply in all regions will also be an effective guarantee against rapid increases in food prices, which will affect vulnerable households.

The highest ambitions for the enhanced production of biodiesel are within palm oil. Presently, a relatively small area of Brazil is covered with palm oil, but the ambition is to have 1 million hectares of palm oil by 2020. As for all other regions, oil palm trees can only yield in a narrow belt along the equator, where there are rainforests. Hence, the only way to justify palm oil expansion is to establish strict prohibitions against deforestation to give way for plantations, allowing only palm oil in what is generally termed 'degraded land'. Three measures have recently been adopted for this purpose; an oil palm zoning, identifying 31.8 million hectares; the oil palm bill (Act 7.326 of 2010); and the Programme for the Sustainable Production of Palm Oil. Based on previous experiences with conduct and failed attempts of regulating this conduct by legislation, it is reasonable to expect that palm oil expansion will not only take place in degraded lands, but also affect natural forests.

\subsection{Management and appropriation of genetic resources}

When reviewing relevant legislation applying to the traditional agricultural model, in Section 2.4 above, the seed law's exemption for traditional cultivars was addressed. The fact that only modern cultivars are given acknowledgement through registration should, however, be criticized. In a report on seed policies and innovation, the Special Rapporteur on the right to food recommended that seed regulation and government-approved seed lists should not exclude farmers' or peasants varieties, and that community registers for such varieties should be developed, and that there should be incentives for wider use of the food produced from such varieties (Special Rapporteur on the right to food 2009c, 21). This 
emphasis is in accordance with the farmers' rights, which are based on a recognition of: the enormous contribution that the local and indigenous communities and farmers of all regions of the world, particularly those in the centres of origin and crop diversity, have made and will continue to make for the conservation and development of plant genetic resources which constitute the basis of food and agriculture production throughout the world (ITPGRFA, Article 9.1).

By stating that plant genetic resources is the basis for global food production and emphasizing crop diversity and conservation, the drafters gave a strong endorsement of the continued role of traditional varieties or peasants' varieties. Embrapa, which is the most important and advanced agricultural research institute in Brazil, provides the following information through its homepage: "Germplasm accessions of species conserved at Embrapa are available for exchange in accordance with ITPGRFA" (Embrapa, 2011a). Moreover, a web site has been constructed "where the collections of different species conserved by Embrapa can be accessed and are available for exchange ... for the multilateral system" (Embrapa, 2011b). As we saw in Section 3.2.3 above, this does not necessarily include plant genetic resources of another 'form' than these resources had when they were received, and which can be subject to patenting.

The UK Commission on Intellectual Property Rights, consisting of both patent attorneys and persons representing industry, noted after visiting one of the leading agricultural research institutes in the developing world: "We were struck both by the vigour with which intellectual property protection was being introduced, and by the conscious effort being made to change the traditionally open culture of research. " (UK Commission on Intellectual Property Rights, 2002, 125). The same institute that this observation applies to emphasizes in its guidelines that patent policy shall be implemented without sacrificing its social mission (ibid). One of the members of the Commission confirms that this leading research institute is Embrapa in Brazil. Without being able to go too deep into the impacts of the increased tendency to patent at Embrapa, and while acknowledging that it is fully possible to license patent product to the conditions that the patent holder sets to less commercial farmers, increased patenting will inevitably lead to an increased commercial orientation for the patent holder. As seen in Section 3.2.1, MDA's National Rural Extension Policy, which encompasses new seed varieties has grown considerably since its introduction in 2003.

Nevertheless, the promotion of monocropping that characterizes particularly the agroindustry in Brazil, the lack of formal recognition of traditional varieties, and the active promotion of patent protection in Embrapa, all point in a certain direction. While biological diversity is praised by Brazilian political authorities, the specific policies do not contribute to maintaining this diversity.

\section{Conclusion}

The Brazilian agricultural boom is more a result of conscious strategies and programmes than a result of 'miracles'. Brazil has comprehensive policies in both the scientific and the social realm - and in policy areas between these two. Several of Brazil's agricultural, science and social policies should be a model for other states.

Exporting the whole model, on the other hand, is not advisable. The Brazilian agricultural model is built on the colonial heritage with a highly unequal land distribution, and the 
Brazilian society is still characterized by disempowerment and partial segregation. To a certain extent, this segregation is justified by the fact that many of the indigenous peoples need to be protected, but overprotection can imply patriarchal thinking and disempowerment. Moreover, the weak enforcement of laws and the adjustment of the laws to accommodate undesired conduct, which in effect facilitates the destruction of vulnerable biomes, implies that "agricultural investment and expansion pose serious environmental challenges" (Deininger and Byerlee, 2010, xxix).

Nevertheless, Brazil has shown impressive achievements in improving productivity in all three agricultural models, including the socio-biodiversity emphasis within the traditional farming model and the agroecological emphasis within family farming. Comprehensive policies applying to all three agricultural models has resulted in more efficient use and reuse of resources, which is the central characteristics of agroeceology (de Wit, 1992, see also Special Rapporteur, on the right to food 2010a). Such policies, however, risks being overshadowed by the continuing agricultural colonization both in the Amazon and in other vulnerable biomes, like the Atlantic Forest (Mata Atlantica) and the Cerrado.

\section{Acknowledgement}

The author wants to thank the Research Council Norway for the generous funding for the project Biofuels and human rights (2009-2013), within which a research field trip to Brazil was conducted in March and April 2011. This chapter builds on the information gathered during this field trip, and the author wants to express his sincere thanks to all those contributing with their time and insight. A report from the field trip is available upon request.

\section{References}

Alston, P. (1984). International Law and the Human Right to Food, In: The Right to Food, P. Alston \& K. Tomasevski (Eds.), pp. 9-68, Martinus Nijhoff Publishers, ISBN 90-2473087-2, Dordrecht.

Bogdanski, A., O. Dubois, C. Jamieson \& R. Krell. (2011). Making Integrated Food-Energy Systems Work for People and Climate. An Overview, FAO, ISBN 978-92-5-106772-7, Rome.

Brazil. (2008). Brazil's second periodic report to the Committee on Economic, Social and Cultural Rights, E/C.12/BRA/2.

Brazilian Ministry of Agrarian Development. (2009). Family Farming in Brazil and 2006's Agricultural and Livestock Census, Brazilian Ministry of Agrarian Development, Brasília.

Collier, P. (2008). Politics of Hunger: How Illusion and Greed Fan the Food Crisis. Foreign Affairs Vol.87, No.1, pp. 67-80, ISSN 0015-7120.

Commission on the Legal Empowerment of the Poor. (2008). Making the Law Work for Everyone Volume I, UNDP, ISBN 978-92-1-126219-3, New York.

Committee on Economic, Social and Cultural Rights. (2009). E/C.12/BRA/CO/2: Concluding observations of the Committee on Economic, Social and Cultural Right: Brazil.

Committee on Economic, Social and Cultural Rights. (1999). E/C.12/1999/5: General Comment 12. The right to adequate food (Art.11). 
Committee on Economic, Social and Cultural Rights. (1991). E/1991/23, 83-87. General Comment No. 3, The nature of States parties obligations.

de Wit, C.T. (1992). Resource Use Efficiency in Agriculture, Agricultural Systems Vol.40, No.1-3, pp. 125-151, ISSN 0308-521X.

Deininger, K. \& D. Byerlee. (2010). Rising Global Interest in Farmland. Can It Yield Sustainable and Equitable Benefits? World Bank, ISBN 978-0-8213-8591-3, Washington DC.

Economist. (2011a). The Indian exception, Vol.399, No.8727 (2 April), p. 55, ISSN 0013-0613.

Economist. (2011b). Plagued by politics [special report on feeding the world], Vol.398, No.8722 (26 February), p. 6, ISSN 0013-0613.

Economist. (2011c). When others are grabbing your land, Vol.399, No.8732 (7 May), p. 55, ISSN 0013-0613.

Economist. (2010a). The Miracle of the Cerrado, Vol.396, No.8697 (28 August), pp. 46-48, ISSN 0013-0613.

Economist. (2010b). Affirmative anticipation, Vol.394, No.8673 (13 March), p. 53, ISSN $0013-$ 0613.

Economist. (2010c). The rights approach, Vol.394, No.8674 (20 March), p. 56, ISSN 0013-0613.

Eide, A. (2009). The Right to Food and the Impact of Liquid Biofuels (Agrofuels), FAO, ISBN 97892-5-106174-9, Rome.

Eide, A. (2007). State Obligations Revisted, In: Food and Human Rights in Development: Vol II: Evolving Issues and Emerging Applications, W. Barth Eide and U. Kracht (Eds.), 137158, Intersentia, ISBN 978-90-5095-459-4, Antwerpen.

Embrapa. (2011a). Plant Accession Area Queries, available from:

<http:/ / mwpin004.cenargen.embrapa.br/MCPDEnglish>

Embrapa. (2011b). ITPGRFA » Brazil, available from:

<http://tirfaa.cenargen.embrapa.br/tirfaa/pg_english/brazil.htm>

Embrapa Agrienergy. (no date). Brazilian Agriculture: Food and Energy for a Sustainable World. Embrapa, Brasília.

Fundação Cultural Palmares. (2011). Comunidades Quilombolas, available from:

$<$ www.palmares.gov.br/?page_id=88>

FAO. (2011). Land tenure and international investments in agriculture. A report by the High Level Panel of Experts on Food Security and Nutrition of the Committee on World Food Security, HLPE Report 2, FAO, Rome

FAO. (2011). International Treaty on Plant Genetic Resources for Food and Agriculture Declarations, available

from: <www.fao.org/Legal/treaties/033s-e.htm>

FAO. (2009). Low Greenhouse Gas Agriculture. Mitigation and Adaptation of Sustainable Farming Systems, FAO, ISBN 978-92-5-106298-2, Rome.

FAO. (2007). Right to food and indigenous peoples, available from:

<www.fao.org/righttofood/wfd/pdf2007/focus_indigenous_eng.pdf>

FAO. (2004). Voluntary Guidelines to Support the Progressive Realization of the Right to Adequate Food in the Context of National Food Security, Adopted by the 127th Session of the FAO Council, FAO, ISBN 92-5-105336-7, Rome.

FAO. (2001a). International Treaty on Plant Genetic Resources for Food and Agriculture, FAO Conference Resolution 3/01, entered into force 29 June 2004.

FAO. (2001b). Land Resource Potential and Constraints at Regional and Country Levels, World Soil Resources Report 90, FAO, Land and Water Development Division: Rome. Fearnside, 
P. M. (2008). The roles and movements of actors in the deforestation of Brazilian Amazonia. Ecology and Society Vol.13, No.1, Article 23 [online], available from: $<$ www.ecologyandsociety.org/vol13/iss1/art23>

Government of Brazil. (2010). Brazil brings traditional people's land into compliance, benefiting 30,000 families in a year, 29 August 2011, available from:

<www.brasil.gov.br/news/history/2010/12/08/brazil-brings-traditional-peoplesland-into-compliance-benefiting-30-000-families-in-a-year>

Haugen, H.M. (2011). Human rights principles: Clarification and application to food and water', In: Max Planck Yearbook of United Nations Law, Volume 15, 419-444. Martinus Nijhoff Publishers, Leiden.

Haugen, H.M. (2009). Food sovereignty - an appropriate approach to ensure the right to food?, Nordic Journal of International Law Vol.78, No.3, pp. 263-292, ISSN 0902-7351.

Haugen, H.M. (2007). The Right to Food and the TRIPS Agreement - With a Particular Emphasis on Developing Countries' Measures for Food Production and Distribution, Martinus Nijhoff Publishers, ISBN 978-90-04-16184-9, Leiden.

HRC. (2009). Poma v. Peru - CCPR/C/95/D/1457/2006 (24 April 2009).

HRC. (1989). General Comment No. 18: Non-discrimination (10 November 1989).

IAASTD (International Assessment of Agricultural Knowledge, Science and Technology for Development). (2009). Agriculture at the Crossroads, Global Report, Island Press, ISBN 978-1-59726-539-3, Washington DC.

Inter-American Court of Human Rights. (2008). Saramaka People v. Suriname, Judgment of 12 August 2008 (Interpretation of the judgment on preliminary objections, merits, reparations, and costs) (Series C No. 185).

IFAD. (2001). Rural Poverty Report 2001 - The Challenge of Ending Rural Poverty, Oxford University Press, ISBN 0-19-924507-X, Oxford and New York.

ILO. (2011). Application of International Labour Standards 2011 (1). Report III (Part 1a). Report of the Committee of Experts on the Application of Conventions and Recommendations. General Report and observations concerning particular countries. International Labour Conference 100th Session, ILO, ISBN 978-92-2-123097-7, Geneva.

ILO. (1989). ILO Convention 169 concerning Indigenous and Tribal Peoples in Independent Countries, 1650 UNTS 28383, entered into force 5 September 1991.

INCRA (National Institute for Colonization and Agrarian Reform). (2008). Instrução Especial $N^{0}$ 20, de 28 de maio de 1980, Estabelece o Módulo Fiscal de cada Município, previsto no Decreto $N^{0} 84.685$ de 06 de maio de 1980, 29 August 2011, available from: www.incra.gov.br/portal/index.php?option=com_docman\&task=doc_download\& gid $=81 \&$ Itemid $=136>$

IPCC (Intergovernmental Panel on Climate Change). (2008). Climate Change 2007: Working Group III: Mitigation of Climate Change (B. Metz, O.R. Davidson, P.R. Bosch, R. Dave, L.A. Meyer. (Eds.)). Cambridge University Press, ISBN 978-05-2170-598-1, Cambridge.

IPSNews 2009, Agribusiness Driving Land Concentration (5 October), available from: $<$ http:/ /ipsnews.net/news.asp?idnews $=48734>$

Klausen, S. (2002). Low schooling for girls, slower growth for all? Cross-country evidence on the effect of gender inequality in education on economic development, World Bank Economic Review Vol.16, No.3, pp. 345-373, ISSN 0258-6770.

Nellemann, C., M. MacDevette, T. Manders, B. Eickhout, B. Svihus, A. Gerdien Prins \& B.P. Kaltenborn. (2009). The Environmental Food Crisis - The Environments's Role in 
Averting a Future Food Crisis. A UNEP Rapid Response Assessment, UNEP -GRID, ISBN 978-82-7701-054-0, Arendal.

Neumanna, K., P.H. Verburg, E. Stehfest \& C. Müller. (2010). The Yield Gap of Global Grain Production: A Spatial Analysis, Agricultural Systems Vol.103, No.5, pp. 316-326, ISSN 0308-521X.

NGO Reporter Brazil. (2009). Brazil of Biofuels: Impacts of Crops on Land, Environment and Society. Soybean, Castor Bean 2009, NGO Reporter Brazil, ISBN 978-85-61252-12-0, São Paulo.Renewable Fuels Association. (2011). World Fuel Ethanol Production, available from:

<http:/ / ethanolrfa.org/pages/World-Fuel-Ethanol-Production>

Santilli, J. (2009). Brazil's Experience in Implementing its ABS Regime: Suggestions for Reform and the Relationship with the International Treaty on Plant Genetic Resources for Food and Agriculture, In: Genetic Resources, Traditional Knowledge and the Law: Solutions for Access and Benefit-Sharing, E. C. Kamau \& G. Winter (Eds.), 177-201, Earthscan, ISBN 978-1-84407-793-9, London.

Sauer, S. (2006). The World Bank's Market-Based Land Reform in Brazil, In: Promised Land: Competing Visions of Agrarian Reform, P. Rosset, R. Patel and M. Courville (Eds.) pp. 177-191, Institute for Food and Development Policy, ISBN 978-0-935028-28-7, New York.

Sauer, S. \& S. Pereira Leite. (2011). Agrarian structure, foreign land ownership, and land value in Brazil. Paper presented at the International Conference on Global Land Grabbing 6-8 April 2011, available from:

$<$ www.future-agricultures.org/index.php?option=com_docman\&Itemid=971>

Smith, L.C., U. Ramakrishnan, A. Ndiaye, L. Haddad \& R. Martorell. (2002). The Importance of Women's Status for Child Nutrition in Developing Countries, IFPRI Report 131, International Food Policy Researc Institute, ISBN 0-89629-134-0, Washington D.C.

E. Smeets, M. Junginger, A. Faaija, A. Walter, P. Dolzan \& W. Turkenburg. (2008). The sustainability of Brazilian ethanol -An assessment of the possibilities of certified production, Biomass and Bioenergy Vol.32, No.8, pp. 781-813, ISSN 0961-9534.

Sparovek, G. \& R.F. Maule. (2009). Negotiated Agrarian Reform in Brazil, In: Agricultural Land Redistribution: Toward Greater Consensus, H.P. Binswanger-Mkhize, C. Bourguignon \& R. van den Brink (Eds.), 291-309, World Bank, ISBN 978-0-82137627-0, Washington D.C.

Special Rapporteur on adequate housing as a component of the right to an adequate standard of living. (2010). A/HRC/13/20/Add.2: Follow-up to country recommendations: Brazil, Cambodia, Kenya.

Special rapporteur on the right to adequate food. (2010a). A/HRC/16/49: Report submitted by the Special Rapporteur on the right to food, Olivier De Schutter.

Special rapporteur on the right to adequate food. (2010b). A/65/281: Interim report of the Special Rapporteur on the right to food, Olivier De Schutter.

Special rapporteur on the right to adequate food. (2009a). A/HRC/13/33/Add.6: Report of the Special Rapporteur on the right to food, Olivier De Schutter. Addendum. Mission to Brazil.

Special rapporteur on the right to adequate food. (2009b). A/HRC/13/33/Add.2, Annex: Largescale land acquisitions and leases: A set of minimum principles and measures to address the human rights challenge. 
Special rapporteur on the right to adequate food. (2009c). A/64/170: Report of the Special Rapporteur on the right to food: Seed policies and the right to food: enhancing agrobiodiversity and encouraging innovation.

Special Rapporteur on the situation of human rights and fundamental freedoms of indigenous peoples (2008). A/HRC/12/34/Add.2: Report from Mission to Brazil.

Special Rapporteur on the situation of human rights and fundamental freedoms of indigenous peoples (2008). A/HRC/9/9/Add.1: Summary of cases transmitted to Governments and replies received.

Special Representative of the Secretary-General on the issue of human rights and transnational corporations and other business enterprises. (2007). A/HRC/4/74: Human rights impact assessments - resolving key methodological questions.

Ssenyonjo, M. (2009). Economic, Social and Cultural Rights in International Law, Hart Publishing, ISBN 978-1-84113-915-9, Oxford.

Sua pesquisa. (no date). Coeficiente de Gini, 29 August 2011, available from: $<w w w . s u a p e s q u i s a . c o m / e c o n o m i a / c o e f i c i e n t e \_g i n i . h t m>T h e$ Rio Times. (2011). Amazon Deforestation Increases Alarming (24 May).

UK Commission on Intellectual Property Rights. (2002). Integrating Intellectual Property Rights and Development Policy, DFID, London.

United Nations. (2007). A/61/295, Annex: Declaration of the Rights of Indigenous Peoples.

United Nations. (1969). Vienna Convention on the Law of Treaties, 1155 U.N.T.S. 331, entered into force 27 January 1980.

United Nations. (1966a). International Covenant on Economic, Social and Cultural Rights, 993 U.N.T.S. 3, entered into force 3 January 1976.

United Nations. (1966b). International Covenant on Civil and Political Rights, 999 U.N.T.S. 171, entered into force 23 March 1976.

United Nations Development Group. (2003). The Human Rights Based Approach to Development Cooperation: Towards a Common Understanding among UN Agencies, available from:

$<$ www.undg.org/archive_docs/6959-

The_Human_Rights_Based_Approach_to_Development_Cooperation_Towards_a_ Common_Understanding_among_UN.pdf>

von Braun, J. S. Fan, R. Meinzen-Dick, M.W. Rosegrant \& A. Nin Pratt. (2008). International Agricultural Research for Food Security, Poverty Reduction, and the Environment, available from:

<www.ifpri.org/sites/default/files/publications/oc58.pdf>

Welling, J. (2008) International Indicators and Economic, Social and Cultural Rights, Human Rights Quarterly Vol.30, No.4, pp. 933-958, ISSN 0275-0392.

Wilkinson, J., B. Reydon \& A. Sabbato. (2010). Dinâmica do mercado de terras na América Latina: o caso do Brasil. Santiago: FAO/Escritório Regional.

World Bank. (2007). World Development Report 2008: Agriculture for Development, World Bank, ISBN 978-0-8213-6807-7, Washington DC.

WTO. (1998). WT/DS58/AB/R, United States - Import prohibition of certain shrimp and shrimp products. 


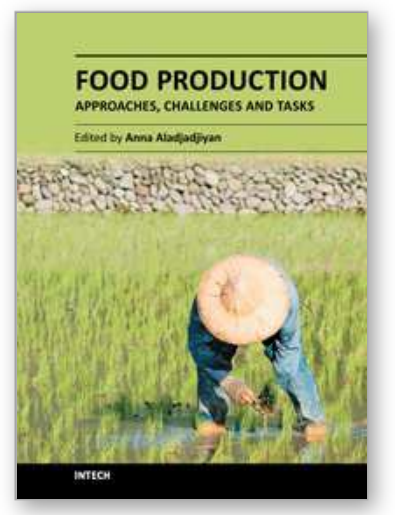

\author{
Food Production - Approaches, Challenges and Tasks \\ Edited by Prof. Anna Aladjadjiyan
}

ISBN 978-953-307-887-8

Hard cover, 270 pages

Publisher InTech

Published online 20, January, 2012

Published in print edition January, 2012

This book is devoted to food production and the problems associated with the satisfaction of food needs in different parts of the world. The emerging food crisis calls for development of sustainable food production, and the quality and safety of the food produced should be guaranteed. The book contains thirteen chapters and is divided into two sections. The first section is related to social issues rising from food insufficiency in the third world countries, and is titled "Sustainable food production: Case studies". The case studies of semi-arid Africa, Caribbean and Jamaica, Burkina Faso, Nigeria, Pacific Islands, Mexico and Brazil are discussed. The second section, titled "Scientific Methods for Improving Food Quality and Safety", covers the methods for control and avoidance of food contaminants. Substitution of chemical treatment with physical, rapid analytical methods for control of contaminants, problems in animal husbandry related to diary production and hormones in food producing animals, approaches and tasks in maize and rice production are in the covered by 6 chapters in this section.

\title{
How to reference
}

In order to correctly reference this scholarly work, feel free to copy and paste the following:

Hans Morten Haugen (2012). ChapterEnhanced Food Production by Applying a Human Rights Approach Does Brazil Serve as a Model of Best Practice?, Food Production - Approaches, Challenges and Tasks, Prof. Anna Aladjadjiyan (Ed.), ISBN: 978-953-307-887-8, InTech, Available from:

http://www.intechopen.com/books/food-production-approaches-challenges-and-tasks/enhanced-foodproduction-by-applying-a-human-rights-approach-does-brazil-serve-as-a-model-of-best-pr

\section{INTECH}

open science | open minds

\section{InTech Europe}

University Campus STeP Ri

Slavka Krautzeka 83/A

51000 Rijeka, Croatia

Phone: +385 (51) 770447

Fax: +385 (51) 686166

www.intechopen.com

\section{InTech China}

Unit 405, Office Block, Hotel Equatorial Shanghai

No.65, Yan An Road (West), Shanghai, 200040, China 中国上海市延安西路65号上海国际贵都大饭店办公楼405单元

Phone: +86-21-62489820

Fax: $+86-21-62489821$ 
(C) 2012 The Author(s). Licensee IntechOpen. This is an open access article distributed under the terms of the Creative Commons Attribution 3.0 License, which permits unrestricted use, distribution, and reproduction in any medium, provided the original work is properly cited. 